\title{
Quantitative PCR-based Assessment of Vaccinia Virus RNA and DNA in Infected Cells
}

Moona Huttunen* and Jason Mercer*

MRC-Laboratory for Molecular Cell Biology, University College London, Gower Street, London WC1E 6BT, United Kingdom

* Corresponding Authors

\begin{abstract}
Quantitative PCR-based methods have proven to be easy to use, cost-effective procedures for the quantification of viral gene expression and viral genome numbers. Quantitative PCR (qPCR) and quantitative reverse transcriptase-PCR (qRT-PCR) are rapid and sensitive approaches that can be used to pinpoint defects in viral DNA replication and transcriptional activity, respectively. Due to the significant nucleotide overlap between Poxviridae these methods can be employed across a wide range of viruses from this family. Here we provide methods for the quantification of vaccinia DNA replication by $q$ PCR and quantification of the three classes of vaccinia gene transcription by qRT-PCR.
\end{abstract}

\section{Key Words}

Vaccinia gene expression, Vaccinia DNA replication, Quantitative PCR (qPCR), Quantitative reverse transcriptase PCR (qRT-PCR) 


\section{Introduction}

Vaccinia virus (VACV) gene expression occurs in three temporal stages: early, intermediate, and late. These gene classes are characterized by divergent promoters and different expression kinetics with early genes expressed between 20 min to 2 hours post infection (hpi), intermediates from 1.5 to $2.5 \mathrm{hpi}$ and late genes from $2.5 \mathrm{hpi}$ onwards (1). Furthermore, early genes are transcribed from within viral cores prior to genome release, while intermediate and late genes are only transcribed after DNA replication, which begins between 1 and 2 hpi (1).

Given this complexity, when assessing the impact of targeted genomic mutations or potential inhibitors on VACV infection, it may be desirable to quantify viral DNA replication and transcriptional activity. Several strategies have been developed to analyze VACV virus DNA replication including: 1- assessing the rate of DNA synthesis by monitoring 3H-thymide incorporation into newly formed DNA (2), 2- quantifying the steady-state levels of viral DNA accumulation by Southern dot-blot hybridization (2), 3visualizing the subcellular sites of DNA replication by incorporation of bromodeoxyuridine (BrdU) with DNA (2), and 4- using Quantitative PCR (qPCR) (3 and 4). For analysis of viral transcription, classical northern blot analysis has been used to investigate the expression of individual VACV genes (5), while RNA sequencing has been recently applied for the global analysis of VACV gene expression (6).

Over the past several years, quantitative PCR (qPCR) has become the leading tool for the detection and quantification of DNA and RNA because of its advantages over traditional endpoint PCR methods. These include single-tube amplification and detection, and no need for post-PCR manipulations (i.e. gel runs/detection). By measuring the amount of DNA after each PCR cycle using fluorescent dyes that yield increasing signal in direct proportion to the number of PCR product molecules 
generated, qPCR provides extremely accurate quantification of the starting material (see Fig. 1).

The protocols described here provide methods for the quantification of VACV DNA replication by qPCR as well as quantification of early, intermediate and late gene transcription activity using quantitative reverse transcriptase-PCR (qRT-PCR) from infected cell culture samples.

\section{Materials}

1. Cell culture medium: Dulbecco's modified Eagle's medium (DMEM) supplemented with 10\% heat-inactivated Fetal Bovine Serum (FBS), 1\% GlutaMAX, 1\% Penicillin/Streptomycin (Pen/Strep).

2. Infection medium: DMEM without supplements.

3. VACV virus, Western Reserve (WR) strain (wild-type [WT]) (see Note 1).

4. HeLa cells (American Type Culture Collection) (see Note 2).

5. 35-mm cell culture dishes.

6. Phosphate buffered saline (PBS).

7. Cell scrapers.

8. $\quad 1.5 \mathrm{ml}$ tubes.

9. Nuclease free water.

10. White 96-well plates for PCR and cap strips (see Note 3).

11. qPCR detection chemistry (see Note 4).

12. qPCR machine (see Note 4).

13. Cell culture incubator $\left(37^{\circ} \mathrm{C}, 5 \% \mathrm{CO}_{2}\right)$.

14. Tabletop centrifuges for $1.5 \mathrm{ml}$ tubes, PCR tubes and PCR 96-well plates.

15. Pipettes and tips. 
16. Ice.

\subsection{Specific materials for $\mathrm{qPCR}$ reaction}

1. Samples: Uninfected (UI), WT infected (WT), and WT infected Cytosine Arabinoside (AraC) treated HeLa cells, 8 hpi.

2. $40 \mathrm{mM}$ AraC diluted in water (4,000 x stock).

3. DNA extraction kit (see Notes 4 and 5).

4. VACV genomic DNA (gDNA) with known DNA concentration (see Note 6).

5. Template DNA (DNA extracted from samples).

6. VACV Early gene C11 specific primers (4).

a. Forward 5'-AAACACACACTGAGAAACAGCATAAA-3'

b. Reverse 5'-ACTATCGGCGAATGATCTGATTA-3'

7. qPCR reaction buffer (for one reaction): $7.6 \mu$ nuclease free water, $0.2 \mu \mathrm{l}$ forward primer $(10 \mu \mathrm{M}), 0.2 \mu \mathrm{l}$ reverse primer $(10 \mu \mathrm{M}), 10 \mu \mathrm{l}$ MESA Blue qPCR MasterMix Plus for SYBR® Assay -MasterMix.

8. Thermomixer $\left(56^{\circ} \mathrm{C}\right)$.

\subsection{Specific materials for two-step qRT-PCR}

1. Samples: Uninfected (UI), WT infected (WT), and WT infected Hoechst treated HeLa cells, 2, 4 and 8 hpi.

2. $16 \mathrm{mM}$ Hoechst diluted in water (80,000 x stock) (see Note 7).

3. RNA extraction kit (see Notes 4 and 5).

4. $\quad 96-100 \%$ Ethanol.

5. $\quad$ 14.3 M beta-mercaptoethanol (BME).

6. Blunt 20-gauge needles.

7. RNAase-free syringes.

8. Reverse Transcriptase enzyme (see Note 4). 
9. $\quad$ Oligo(dT) $12-18(500 \mu \mathrm{g} / \mathrm{ml})$.

10. dNTP Mix (10 mM each).

11. Extracted sample mRNA.

12. PCR tubes.

13. Endpoint PCR machine (see Note 8) or sterile water bath/heat block capable of heating $42^{\circ} \mathrm{C}, 65^{\circ} \mathrm{C}$, and $70{ }^{\circ} \mathrm{C}$.

14. Mixture of Oligo(dT) $)_{12-18}$ and dNTP Mix (for one reaction): $1 \mu$ l Oligo(dT) $)_{12-18}$ (500 $\mu \mathrm{g} / \mathrm{ml}), 1 \mu \mathrm{l}$ dNTP Mix (10 mM each), $9 \mu \mathrm{l}$ nuclease free water.

15. Buffer mixture (for one reaction): $4 \mu \mathrm{l}$ XX First-strand buffer (provided by the kit), $2 \mu \mathrm{l}$ 0.1M DTT (provided by the kit) and $1 \mu \mathrm{l}$ nuclease free water.

16. VACV Early gene J2 specific primers (4).
a. Forward 5'-TACGGAACGGGACTATGGAC-3'
b. Reverse 5'-GTTTGCCATACGCTCACAGA-3'

17. VACV Intermediate gene G8 specific primers (4).
a. Forward 5'-AATGTAGACTCGACGGATGAGTTA-3'
b. Reverse 5'-TCGTCATTATCCATTACGATTCTAGTT-3'

18. VACV Late gene F17 specific primers (4).
a. Forward 5'-ATTCTCATTTTGCATCTGCTC-3'
b. Reverse 5'-AGCTACATTATCGCGATTAGC-3'

19. Glyceraldehyde 3-phosphate dehydrogenase (GAPDH) specific primers (Housekeeping gene) (4).
a. Forward 5'-AAGGTCGGAGTCAACGGATTTGGT-3'
b. Reverse 5'-ACAAAGTGGTCGTTGAGGGCAATG-3' 


\section{Methods}

Make sure all reagents are sterile, pure, and PCR-grade. Use sterile technique.

\subsection{Quantifying VACV DNA replication using qPCR}

\subsubsection{VACV virus infection}

1. Infect confluent 35-mm dishes of HeLa cells (see Notes $\mathbf{2}$ and 9) at multiplicity of infection (MOI) of 10 with WT VACV in infection medium.

2. Incubate in cell culture incubator for 1 hour. UI-sample is treated similarly but without virus.

3. Remove infection medium and replace with $1 \mathrm{ml}$ cell culture medium.

4. For AraC-sample replace infection medium with cell culture medium containing 1x AraC.

5. Place samples in cell culture incubator for 7 hours.

6. Scrape cells and place in $1.5 \mathrm{ml}$ tubes.

7. Centrifuge for $5 \mathrm{~min}$ at $300 \mathrm{xg}$.

8. Discard the supernatant and freeze the cell pellets $\left(-20^{\circ} \mathrm{C}\right.$ or $\left.-70{ }^{\circ} \mathrm{C}\right)$ or proceed with total DNA extraction (Subheading 3.1.2.) (see Note 10).

\subsubsection{Total DNA extraction}

Extract total DNA from samples with Qiagen DNeasy ${ }^{\circledR}$ DNA extraction kit (see Notes 4 and 5). Steps 3-7 should be performed in virus hood after which it is safe to move to a PCR-quality lab bench.

1. Prepare Buffers AL, AW1, and AW2 according to manufacture's instructions.

2. Preheat thermomixer to $56{ }^{\circ} \mathrm{C}$.

3. $\quad$ Resuspend cell pellets from Subheading 3.1.1. step 8 in $200 \mu$ l PBS (see Note 10).

4. Lyse samples by adding $20 \mu$ proteinase K (see Note 11 ). 
5. Add $200 \mu \mathrm{l}$ Buffer AL, mix by vortexing (see Note 12).

6. Incubate at $56^{\circ} \mathrm{C}$ for $10 \mathrm{~min}$.

7. Add $200 \mu$ l ethanol (96-100\%), mix by vortexing (see Note 13).

8. Pipet cell lysates into provided spin columns.

9. Centrifuge at $6,000 \times \mathrm{g}$ for $1 \mathrm{~min}$.

10. Discard the flow-through and collection tube.

11. Place the spin column into a new collection tube and add $500 \mu \mathrm{l}$ Buffer AW1.

12. Centrifuge for $1 \mathrm{~min}$ at $6,000 \mathrm{xg}$.

13. Discard the flow-through and collection tube.

14. Place the spin column into a new collection tube and add $500 \mu \mathrm{l}$ Buffer AW2.

15. Centrifuge for $3 \mathrm{~min}$ at $20,000 \mathrm{xg}$ (see Note 14).

16. Place the spin column in a clean $1.5 \mathrm{ml}$ tube and add $200 \mu \mathrm{l}$ nuclease free water directly onto the spin column membrane.

17. Incubate at room temperature for $1 \mathrm{~min}$.

18. Centrifuge for $1 \mathrm{~min}$ at $6,000 \mathrm{xg}$ to elute the DNA (see Note 15).

19. Continue straight to qPCR (Subheading 3.1.3.) or store the samples at $-80{ }^{\circ} \mathrm{C}$ or $-20^{\circ} \mathrm{C}$.

\subsection{3. qPCR}

Quantify the amount of viral DNA in samples using commercial detection chemistry (for example MESA Blue qPCR MasterMix Plus for SYBR ${ }^{\circledR}$ Assay, Eurogentec, see Note 4).

1. Thaw all reagents and keep them on ice. Mix all reagents well and spin them down prior to pipetting.

2. Plan your pipetting/plate layout (see Note $\mathbf{1 6}$ and Table 1).

3. Prepare VACV gDNA dilution series (see Notes 6 and 17). 
4. $\quad$ Prepare the template DNA (extracted in Subheading 3.1.2.) by diluting them 1:200 in nuclease free water (see Note 18).

5. Prepare qPCR reaction buffer being sure to mix thoroughly by inversion and spin down (see Note 19).

6. Pipette $2 \mu \mathrm{l}$ of diluted template DNA into bottom of the wells as planned (see Table 1).

7. Add $18 \mu \mathrm{l}$ of qPCR reaction buffer into each well (final volume $20 \mu \mathrm{l}$, see Note 20).

8. Spin samples down ( $3 \mathrm{~min}, 300 \mathrm{xg})$.

9. Run qPCR according to qPCR reagent's instructions (see Note 21).

\subsubsection{Quantification of $q P C R$ results}

All qPCR machines report amplification results in a similar way. Usually the first graph to look at is the amplification curve (see Fig. 2). The threshold cycle (Ct) is the cycle number at which the fluorescent signal of the reaction crosses the threshold (see Note 22).

Since several factors can affect qPCR result analysis and comparison (see Note 23). In order to make high-quality data comparison, it is important to use correct control samples, data normalization, and quantification methods (see Note 24 and Table 2). This section describes how to do absolute quantification from the raw qPCR data (see Note 25).

1. To form a standard curve, plot the VACV gDNA concentration dilutions against their corresponding Ct values (see Fig. 3).

2. Determine function for the curve. The function for this example standard curve is $y=-1.492 \ln (x)+25.415$ 
3. Calculate the absolute amount of starting material in your samples by plugging the average sample Ct values from your raw data into standard curve equation (see Note 26 and Table 3).

4. Check your positive and negative controls and evaluate the quality of the results (see Table 3 and Subheading 3.1.5.).

\subsubsection{Evaluation of qPCR results}

This section describes how to evaluate the qPCR results using the standard and melting curves. The overall PCR efficiency can be checked from the slope value of the standard curve (see Fig. 3B). The slope of the standard curve should be between -3.1 and -3.58 . The linearity of the standard curve $\left(\mathrm{R}^{2}\right.$ ) should be higher than 0.985 (see Fig. 3B). When using detection method based on SYBR Green I, the system specificity should be tested by running a melting curve analysis at the end of the qPCR run (see Fig. 4). A specific melting curve should show one, unique melting peak per primer pair. If additional peaks appear, the primer pair is annealing with itself and you should avoid using it.

\subsection{Quantifying VACV transcriptional activity using qRT-PCR}

\subsubsection{VACV virus infection}

1. Infect confluent 35-mm dishes of HeLa cells (see Note 2 and 9) at MOI 10 with WT VACV in infection medium.

2. Incubate in cell culture incubator for 1 hour. UI-sample is treated similarly but without virus.

3. Remove infection medium and replace with $1 \mathrm{ml}$ cell culture medium.

4. For Hoechst-sample replace infection medium with cell culture medium containing 1x Hoechst.

5. Place samples in cell culture incubator for 1, 3 or 7 hours.

6. At indicated time points, scrape cells and transfer to $1.5 \mathrm{ml}$ tubes. 
7. Centrifuge for $5 \mathrm{~min}$ at $300 \mathrm{xg}$.

8. Determine the number of cells before continuing to the next step (see Note 27).

9. Discard the supernatant and proceed with total RNA extraction (Subheading 3.2.2.) or freeze cell pellets at $-80{ }^{\circ} \mathrm{C}$ (see Notes 10 and 28).

\subsubsection{Total RNA extraction}

Harvest total RNA from infected cells using a commercial kit according to the manufacturer's instructions (for example RNeasy ${ }^{\circledR}$, Qiagen) (see Notes 4 and 5). Steps 3-6 should be performed in a virus hood after which it is safe to move to a PCR-quality lab bench.

1. Add BME to Buffer RLT according to manufacturer's protocol (10 $\mu$ BME per 1 ml Buffer RLT) (see Note 29).

2. Prepare Buffer RPE according to manufacturer's instructions.

3. $\quad$ Disrupt cell pellets from Subheading 3.2.1. step 8 by adding $350 \mu \mathrm{l}$ Buffer RLT (see Notes 30, 31 to 32).

4. Mix by vortexing or pipetting (see Note 35 ).

5. Homogenize the lysate by passing it through a 20-gauge needle at least 5 times (see Notes 33 and 34).

6. Add $350 \mu \mathrm{l} 70 \%$ ethanol to the homogenized lysate (see Note 35). After this step it is safe to move from virus hood to PCR-quality lab bench.

7. Mix well by pipetting (see Note 36 ).

8. Transfer up to $700 \mu \mathrm{l}$ of the sample (including any precipitate) to a supplied spin column.

9. Centrifuge for $15 \mathrm{~s}$ at $8,000 \mathrm{xg}$.

10. Discard the flow-through (see Note 37).

11. Add $700 \mu$ l Buffer RW1 to the spin column. 
12. Centrifuge for $15 \mathrm{~s} 8,000 \mathrm{xg}$.

13. Discard the flow-through (see Note 38).

14. Add $500 \mu \mathrm{l}$ Buffer RPE to the spin column (see Note 39).

15. Centrifuge for $15 \mathrm{~s}$ at $8,000 \mathrm{xg}$.

16. Discard the flow-through.

17. Add $500 \mu \mathrm{l}$ Buffer RPE to the spin column.

18. Centrifuge for $2 \mathrm{~min}$ at $8,000 \mathrm{xg}$ (see Note 40).

19. Place the spin column in a new $1.5 \mathrm{ml}$ tube.

20. Add $30 \mu \mathrm{l}$ nuclease free water directly to the spin column membrane (see Note 41).

21. Centrifuge for $1 \mathrm{~min}$ at $8,000 \mathrm{xg}$ to elute the RNA (see Note 42).

22. Continue straight to qRT-PCR step (Subheading 3.2.3.) or store samples at -80 ${ }^{\circ} \mathrm{C}$ or $-20{ }^{\circ} \mathrm{C}$.

\subsubsection{Two-step qRT-PCR (reverse transcription step)}

After the extraction, a portion of total RNA is reverse transcribed into cDNA with reverse transcriptase enzyme (for example SuperScript II, Invitrogen, see Notes 4 and 43) and primers according to manufacturer's protocol.

1. Plan your final qPCR plate layout (see Notes 16,44 , and Table 4).

2. Thaw 5X First-Strand Buffer and 0.1 M DTT (both provided with the kit) at room temperature just prior to use and refreeze immediately.

3. Measure total RNA concentrations of your samples from Subheading 3.2.2. step 22 with Nanodrop or other spectrometric method.

4. Calculate the total volume of RNA needed for the reverse transcription reaction. (see Note 45). 
5. Prepare mixture of Oligo(dT)12-18 and dNTP Mix in nuclease-free PCR tube. Make enough for all reactions (see Notes 46 and 47).

6. Pipette $11 \mu \mathrm{l}$ of Oligo(dT) ${ }_{12-18}$, dNTP Mix in pre-labelled PCR tubes.

7. Add $1 \mu \mathrm{l}$ of extracted RNA sample in each tube (see Note 45).

8. Spin samples down briefly.

9. Heat samples to $65^{\circ} \mathrm{C}$ for 5 min and quickly chill on ice (see Note 8).

10. Collect the contents by brief spin.

11. Prepare enough buffer mixture for all reactions.

12. Add $7 \mu \mathrm{l}$ buffer mixture into each reaction tube.

13. Mix tube gently and spin briefly.

14. Incubate at $42{ }^{\circ} \mathrm{C}$ for $2 \min$ (see Notes 8 and 48).

15. Add $1 \mu \mathrm{l}(200$ units) SuperScript II reverse transcriptase into each tube (see Note 49).

16. Mix gently and spin briefly.

17. Incubate at $42{ }^{\circ} \mathrm{C}$ for $50 \mathrm{~min}($ see Notes 8 and $\mathbf{5 0}$ ).

18. Inactivate the reaction by heating at $70{ }^{\circ} \mathrm{C}$ for $15 \mathrm{~min}$ (see Note 8).

19. With newly synthesized cDNA (final volume $20 \mu \mathrm{l}$ ), continue to qPCR step (Subheading 3.2.3.; see Note 51).

\subsubsection{Two-step qRT-PCR (qPCR step)}

Quantify the amount of viral cDNA in samples using commercial detection chemistry (for example MESA Blue qPCR MasterMix Plus for SYBR ${ }^{\circledR}$ Assay, Eurogentec, see Note 4).

1. Thaw all reagents and keep them on ice. Mix all reagents well and spin them down prior to pipetting.

2. Plan your pipetting/plate layout (see Note 16 and Table 4). 
3. Prepare qPCR reaction buffer for all samples (see Notes 19 and 52).

4. Mix thoroughly by inversion and spin down.

5. Pipette $2 \mu \mathrm{l}$ of template cDNA into bottom of the wells as planned (see Note $\mathbf{1 6}$ and Table 4).

6. Add $18 \mu \mathrm{l}$ of qPCR reaction buffer to each well (final volume $20 \mu \mathrm{l}$, see Note 20).

7. Spin samples down ( $3 \mathrm{~min}, 300 \mathrm{xg})$.

8. Run qPCR according to qPCR reagent's instructions (see Note 21).

\subsubsection{Quantification of qRT-PCR results}

The last step of qRT-PCR is essentially a normal qPCR reaction as already outlined in

Subheading 3.1.4. This chapter describes how to calculate the relative amount of gene of interest normalized against the housekeeping gene (see Note 53). Start by calculating $\Delta \mathrm{Ct}$ values for $\mathrm{qRT}$-PCR results. This is done by subtracting the $\mathrm{Ct}$ value of the housekeeping gene from the Ct value of the same 'gene of interest' sample (see Tables 5A and 5B). For example $\mathrm{Ct}_{\mathrm{UI} J 2}-\mathrm{Ct}_{\mathrm{UI} \text { GAPDH: }} 31.86-18.04=13.82$. Next, $\Delta \Delta \mathrm{Ct}$ values are calculated by subtracting the $\Delta \mathrm{Ct}$ value of the chosen control sample from the $\Delta \mathrm{Ct}$ value of the gene of interest (see Table 5C). For example: $\Delta \mathrm{Ct}_{\mathrm{UI} J 2}-\Delta \mathrm{Ct}_{\mathrm{WT}} \mathrm{J} 2: 13.82-(-5.65)=$ 19.47. Finally calculate the final relative quantification from the $\Delta \Delta \mathrm{Ct}$ values with equation $0.5^{\wedge}(\Delta \Delta \mathrm{Ct})$ (see Table 5D). For example for UI $2 \mathrm{~h}$ J2 sample: $0.5^{\wedge} 19.47=1.38$ $\mathrm{x} 10^{\wedge}-6$

\section{Notes}

1. Besides WR, many other strains of VACV (e.g., Copenhagen, IHD-J) can be used in qPCR assays.

2. Besides HeLa, other cell lines can also be used.

3. Depending on number of samples, individual or strips of PCR tubes can also be used. Check the compatibility between PCR tubes and qPCR machine. 
4. Several companies provide qPCR machines, qPCR detection chemistries, nucleic acid extraction kits, and reverse transcriptase enzymes. It is important to make sure that they are compatible. Examples of such reagents and machines:

a. qPCR machine: CFX Connect Real-Time System (BioRad)

b. qPCR detection chemistry: MESA Blue qPCR MasterMix Plus for SYBR ${ }^{\circledR}$ Assay (Eurogentec)

c. DNA extraction kit: DNeasy ${ }^{\circledR}$ Blood and Tissue extraction kit (Qiagen)

d. RNA extraction kit: RNeasy ${ }^{\circledR}$ RNA extraction kit (Qiagen)

e. Reverse transcriptase enzyme: SuperScript ${ }^{\mathrm{TM}}$ II reverse transcriptase (Invitrogen)

5. It is highly recommended to use commercially available kits for extraction of nucleic acids and qPCR detection. The nucleic acid extraction step is probably the most critical in any qPCR assay. The quality of the extraction will influence the quality of the DNA detection and quantification. With biological samples it is also very important to ensure the reproducibility of the extraction and any following steps. For qPCR detection, companies usually provide so-called Core Kits that contain all essential components (except the template nucleic acid and primers) in separate tubes or MasterMixes in which all essential components are already mixed in an optimized way. The advantage of Core Kits is that each component can be separately optimized. However, MasterMixes can save time and provide high reproducibility and ease of use.

6. VACV gDNA (7) concentration is measured by spectrometric method (Nanodrop).

7. Hoechst is an inhibitor of VACV intermediate and late gene transcription (4). 
8. Endpoint PCR machine can be used in heating and cooling steps of two-step qRTPCR.

9. In order to obtain optimum nucleic acid yield and quality, it is important to ensure that an appropriate number of cells is used in the extraction step. See manufacturer's instructions.

10. Fresh or frozen cell pellets can be used in nucleic acid extraction. Best results are obtained with fresh material or material that has been immediately frozen and stored at $-20^{\circ} \mathrm{C}$ or $-70^{\circ} \mathrm{C}$. With DNA samples, avoid freeze/thaw cycles, since this reduces DNA size. If using frozen cell pellets, allow cells to thaw before adding PBS (Subheading 3.1.2., step 3).

11. The activity of proteinase $\mathrm{K}$ provided with this kit is $600 \mathrm{mAU} / \mathrm{ml}$ solution.

12. Mix sample and Buffer AL immediately and thoroughly by vortexing or pipetting to yield a homogenous solution.

13. Sample and ethanol should be mixed thoroughly to yield a homogenous solution.

14. It is important to dry the membrane of the spin column by centrifuging, since residual ethanol may interfere with subsequent reactions. Remove the spin column carefully so that the column does not come into contact with the flowthrough.

15. DNA can also be eluted into provided Buffer AE. Elution with $100 \mu \mathrm{l}$ instead of $200 \mu \mathrm{l}$ increases the final DNA concentration in the eluate, but also decreases the overall DNA yield. For maximum DNA yield, repeat elution once as described in step 18. If the eluate volume exceeds $200 \mu \mathrm{l}$, use $2 \mathrm{ml}$ tube.

16. Planning the pipetting and plate layout helps you to determine what samples and the quantity of reagents needed. It is important to make a technical duplicate, preferably triplicate, for each sample and include all necessary control samples 
(positive and negative). The reproducibility of an experiment is indicated by replicates (technical and biological). An example plate layout for qPCR can be found in Table 1 and for qRT-PCR in Table 4.

17. Dilution series for absolute quantification needs to cover the whole range of concentrations within your samples. In this example experiment we initially diluted stock VACV gDNA (100 ng/ $\mu \mathrm{l})$ to $20 \mathrm{ng} / \mu \mathrm{l}$ solution. This dilution was used as our first gDNA dilution in the series. From there we made the following dilutions (all 1:10): $2 \mathrm{ng} / \mu \mathrm{l}, 0.2 \mathrm{ng} / \mu \mathrm{l}, 20 \mathrm{pg} / \mu \mathrm{l}, 2 \mathrm{pg} / \mu \mathrm{l}, 0.2 \mathrm{pg} / \mu \mathrm{l}, 0.02 \mathrm{pg} / \mu \mathrm{l}$ and $0.002 \mathrm{pg} / \mu \mathrm{l}$ (dilutions 2 to 8). It is recommended to make enough dilutions for all your biological replicates at once.

18. In this example experiment the samples were normalized by volume (all samples were diluted 1:200 and equal volumes were used in the qPCR assay).

19. Calculate the required amount of qPCR reaction buffer and prepare at least $10 \%$ extra for avoid running short. In this example experiment you will need $18 \mu \mathrm{l}$ qPCR reaction buffer per sample.

20. Pipette onto walls of the well, do not touch the bottom/template DNA, this way you can use the same tip throughout the plate.

21. Use cycle temperatures and times suggested by qPCR detection chemistry provider. The qPCR machine might do the melting curve automatically or you have to activate it yourself. For MESA Blue qPCR MasterMix Plus:
a. $5 \min 95^{\circ} \mathrm{C}$ (nuclease activation)
b. $15 \sec 95^{\circ} \mathrm{C}$ followed by $1 \min 60^{\circ} \mathrm{C}$ ( 40 cycles)
c. Perform a melting curve (or hold at $50{ }^{\circ} \mathrm{C}$ forever) 
22. Low Ct values means the fluorescence crosses the threshold early, and that the amount of target in the sample is high. It is important to quantify the qPCR reaction in the early part of the exponential phase as opposed to when the reaction reaches the plateau phase when one of the reagents in the reaction becomes limited (see Fig. 2). As a rule of thumb technical replicates that have more than $0.5 \mathrm{Ct}$ difference should be avoided.

23. Several factors such as the amount of starting material, enzymatic efficiencies, and differences in experimental conditions may have an effect in analysis and qPCR result comparison.

24. The two major methods of quantification of qPCR results are the absolute quantification and the relative quantification. In absolute quantification, a dilution series of known template concentrations can be used to establish a standard curve (see Fig. 3). This can then be used for determining the initial starting amount of the target template in experimental samples (see Table 3). In relative quantification the expression of a gene of interest in one sample (i.e. treated) is compared to expression of the same gene in another sample (i.e. untreated). The results are presented as fold-change. In relative quantification a housekeeping gene is used as a normalizer for experimental variability (Subheading 3.2.4.).

25. Controls in this example experiment are "no template" (negative) and "same target, different sample" (positive).

26. For absolute quantification of the starting amount of VACV genome in samples, change the equation to: $\mathrm{x}=\mathrm{e}^{\wedge}((25.415-\mathrm{y}) / 1.492)$.

27. It is essential to use the correct number of cells to obtain optimal RNA yield and purity. See manufacturer's instructions. 
28. Incomplete removal of infection medium will inhibit lysis in following steps and dilute the lysate, reducing the RNA yield.

29. Dispense BME in a fume hood wearing appropriate protective clothing. Buffer RLT containing BME can be stored at room temperature for up to 1 month.

30. Frozen pellets should be thawed before moving onto next step.

31. The volume of Buffer RLT depends on the initial number of cells. See manufacturer's instructions.

32. For direct lysis of cell monolayer, add the appropriate volume of Buffer RLT to the cell culture dish. Collect the lysate by scraping the cells and pipetting suspension into $1.5 \mathrm{ml}$ tube. For pelleted cells, loosen the cell pellet thoroughly by flicking the tube. Incomplete loosening of the cell pellet or insufficient mixing leads to inefficient lysis and reduced RNA yields. Add appropriate volume of Buffer RLT.

33. Other homogenization methods include commercial homogenizing spin columns and mechanical homogenizers. See more info in manufacture's protocol.

34. Incomplete homogenization leads to significantly reduced RNA yields and can also cause clogging of spin columns in subsequent steps.

35. You should add 1 volume of $70 \%$ ethanol. The volume of lysate may be less than the original $350 \mu \mathrm{l}$ due to the loss during homogenization. Precipitates may be visible after addition of ethanol. This does not affect the procedure.

36. Do not centrifuge.

37. If the sample volume exceeds $700 \mu \mathrm{l}$, repeat steps 9 to 11 . Discard the flowthrough after each centrifugation.

38. Remove the spin column from the collection tube carefully so that the column does not contact the flow-through. Empty the collection tube completely. 
39. Ensure that ethanol is added to Buffer RPE before use. See manufacture's instructions.

40. The long centrifugation step dries the spin column membrane (residual ethanol may interfere with downstream reactions). Remove the spin column from the collection tube carefully so that the column does not contact the flow-through.

41. Add 30-50 $\mu$ l nuclease free water.

42. If the expected RNA yield exceeds $30 \mu \mathrm{g}$, repeat steps 21 and 22 using another 30-50 $\mu \mathrm{l}$ nuclease free water or using the elute form step 22. If using the elute from step 22, the RNA yield will be less when obtained using a second volume of nuclease free water, but the final RNA concentration will be higher.

43. The qRT-PCR can be done in one or two steps, both of which have their own pros and cons. One-step qRT-PCR combines the cDNA synthesis reaction and qPCR reaction in the same tube, simplifying reaction setup and reducing the possibility of contamination between the reverse transcription and qPCR steps. Genespecific primers are required for one-step qRT-PCR, and it is usually less sensitive than two-step qRT-PCR. In this example experiment were using the two-step qRT-PCR method. Two-step qRT-PCR starts with the reverse transcription of total mRNA into cDNA using a reverse transcriptase. Usually the cDNA synthesis reaction is primed using a mixture of commercially available random primers or a mixture of Oligo(dT) and random primers. These should give an equal representation of all targets in later qPCR applications. The twostep qRT-PCR also gives the possibility to stock cDNA and is the more flexible of the two options as the two reactions (reverse transcription and qPRC) can be optimized separately. One disadvantage with the two-step qRT-PCR is that as it 
requires more pipetting, there is a higher risk of RNase inhibitors to influence the qPCR reaction.

44. Since this example experiment is going to use relative quantification, quantifications of genes of interest (J2, G8 or F17) and the housekeeping gene (GAPDH) has to be made from each sample (see Table 4).

45. In this example we are pipetting identical mRNA volumes of different samples and we decided to reverse transcribe $\sim 500$ ng of RNA per sample. In all samples RNA concentrations (measured with Nanodrop) were 450-590 ng/ $\mu \mathrm{l}$, so we decided to continue with $1 \mu \mathrm{l}$ of each sample to reverse transcription reaction. Manufacture's protocol gives a working range for the enzyme. With SuperScript ${ }^{\mathrm{TM}}$ II enzyme the $20 \mu \mathrm{l}$ reaction volume can be used for $1 \mathrm{ng}-5 \mu \mathrm{g}$ of total RNA or 1-500 ng of mRNA.

46. Calculate your need reaction buffer and prepare at least $10 \%$ extra for avoid running out. In this example experiment you will need $11 \mu \mathrm{l}$ reaction buffer per sample.

47. Instead of Oligo(dT) $)_{12-18}(500 \mu \mathrm{g} / \mathrm{ml})$, random primers $(50-250 \mathrm{ng})$ or genespecific primer (2 pmole) can be used.

48. If random primers are used, incubate at $25^{\circ} \mathrm{C}$ for $2 \mathrm{~min}$.

49. If less than $1 \mathrm{ng}$ of RNA is used, reduce the amount of reverse transcriptase enzyme to $0.25 \mu \mathrm{l}$ and add nuclease free water to obtain the final volume of $20 \mu \mathrm{l}$.

50. If random primers are used, incubate tube at $25{ }^{\circ} \mathrm{C}$ for $10 \mathrm{~min}$ prior to $50 \mathrm{~min}$ incubation.

51. Amplification of some large PCR targets $(>1 \mathrm{~kb})$ may require removal of RNA complementary to the cDNA. This can be done by adding $1 \mu \mathrm{l}$ ( 2 units) of E. coli RNase $\mathrm{H}$ to the tube and incubating at $37^{\circ} \mathrm{C}$ for $20 \mathrm{~min}$. 
52. Forward and reverse primers for genes of interest (VACV early, intermediate and late genes $\{\mathrm{J} 2, \mathrm{G} 8, \mathrm{~F} 17\}$ and housekeeping gene $\{\mathrm{GAPDH}\}$ ) are diluted in nuclease free water $(10 \mu \mathrm{M})$. In this example experiment $\mathrm{J} 2$ expression was checked from 2h sample, G8 from 4h sample and F17 from 8h sample. Since GAPDH serves as a housekeeping gene (and normalizing factor) in this experiment, its expression should be checked from all samples.

53. In the example experiment controls are 'no template' (negative) and 'same sample, different target' (positive).

Acknowledgements: $\mathrm{HM}$ and JM are supported by core funding to the MRC Laboratory for Molecular Cell Biology at University College London (J.M.), the European Research Council (649101-UbiProPox) and the UK Medical Research Council (MC_UU12018/7).

\section{References}

1. Moss, B. (2001) Poxviridae: the viruses and their replication, in Fields Virology (Knipe, D. M. and Howley, P. M., eds.), Lippincott William \& Wilkins, Philadelphia, PA, Vol. 2, pp. 2849-2883.

2. Traktman, P. and Boyle, K. (2004) Methods for Analyzing of Poxvirus DNA Replication, in Methods in Molecular Biology (Isaacs, S. N., ed), Humana Press, Totowa, New Jersey, Vol. 1., pp. 169-185.

3. Senkevich, T. G., Koonin E. V. and Moss, B. (2009) Predict Poxvirus FEN1-like Nuclease Required for Homologous Recombination, Double-strand Break Repair and Full-size Genome Formation. PNAS 106, 17921-17926,

4. Yakimovich, A., Huttunen, M., Zehnder, B., Coulter, L. J., Gould, V., Schneider, C., et al. (2017) Inhibition of poxvirus gene expression and genome replication by bisbenzimide derivatives. J Virol 91, e00838-17. 
5. Jones, E. V., and Moss, B. (1985) Transcriptional Mapping of the Vaccinia Virus DNA Polymerase Gene. J Virol 53, 312-315.

6. Yang, Z., Bruno, D. P., Martens, G. A., Porcella, S. F. and Moss, B. (2010) Simultaneous high-resolution analysis of vaccinia virus and host cell transcriptomes by deep RNA sequencing. PNAS 107, 11513-11518.

7. Roper, R. (2004) Rapid Preparation of Vaccinia Virus DNA Template for Analysis and Clonin by PCR, in Methods in Molecular Biology (Isaacs, S. N., ed), Humana Press, Totowa, New Jersey, Vol. 1., pp. 113-118.

Fig 1
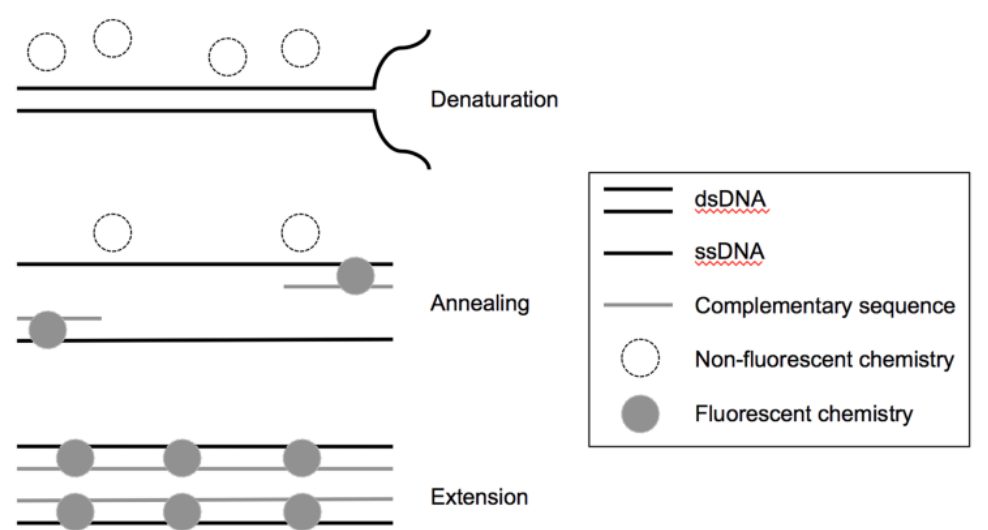

Fig 1. qPCR reaction. Just like in endpoint PCR, there are three major steps that make up each cycle in qPCR reaction: denaturation, annealing and extension. During denaturation high temperature "melts" 
double-stranded DNA into single strands and loosens secondary structure of single-stranded DNA.

Complementary sequences (primers) will hybridize during annealing, and at the same time fluorescent dye binds to newly formed hybrids. At optimal temperature DNA polymerase becomes active, and the primer extension occurs.

Fig 2

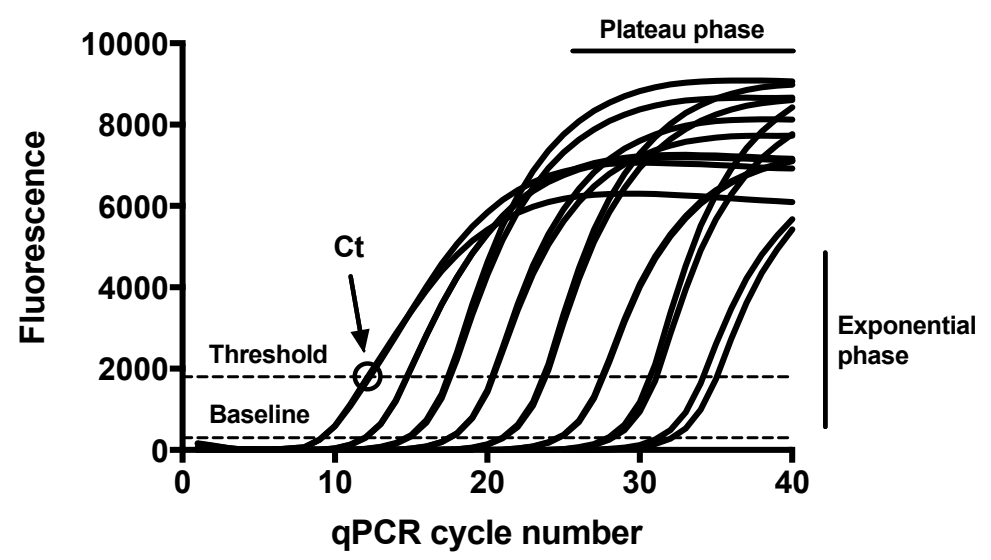

Fig 2. Amplification curves. The amplification curve shows the increase of detected fluorescence on the Yaxis and the PCR run cycle number on the X-axis. The threshold is the level of fluorescence above the 
baseline at which the signal can be considered above background. The threshold cycle ( $\mathrm{Ct}$ ) is the cycle number at which the fluorescent signal of the reaction crosses the threshold. In the plateau phase one of the reagents in the reaction becomes limited. 
Fig 3

A

\begin{tabular}{|l|l|}
\hline $\begin{array}{l}\text { Vaccinia } \\
\text { gDNA (pg) }\end{array}$ & Average Ct \\
\hline 0.004 & 34.88 \\
\hline 0.04 & 29.49 \\
\hline 0.4 & 26.37 \\
\hline 4 & 23.09 \\
\hline 40 & 19.74 \\
\hline 400 & 16.12 \\
\hline 4000 & 13.22 \\
\hline 40000 & 10.13 \\
\hline
\end{tabular}

B

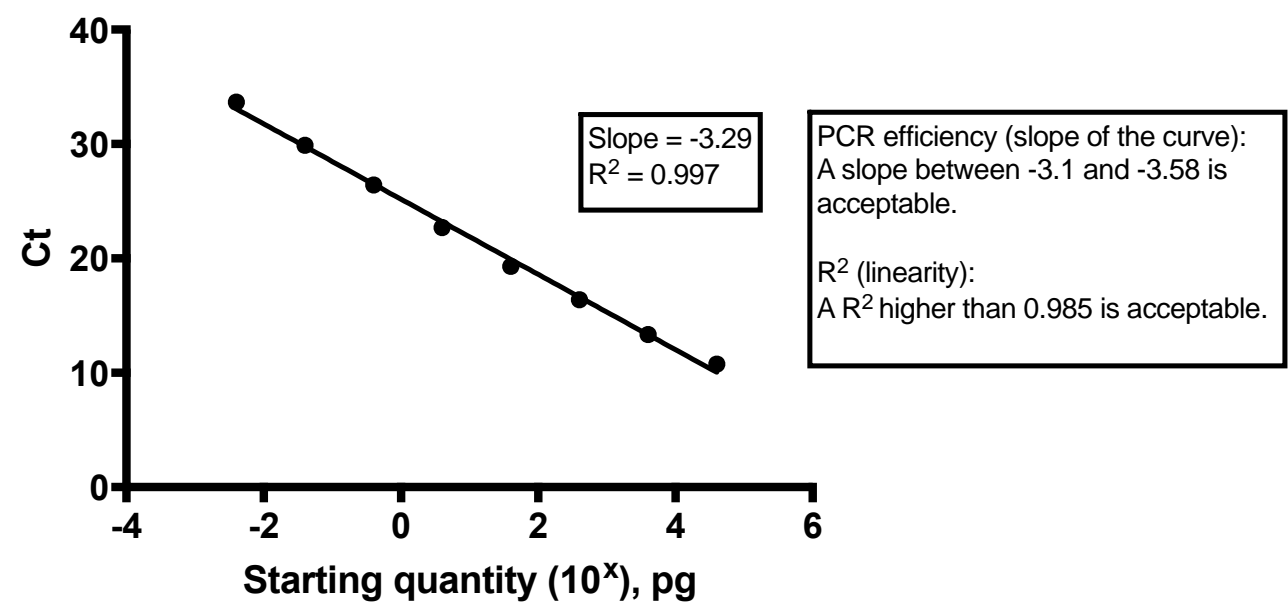

Fig 3. A standard curve. A. A standard curve is established by a dilution series of known template concentrations. B. To plot the standard curve each known concentration in the dilution series (x-axis) is plotted against the $\mathrm{Ct}$ value for that concentration (y-axis). From the standard curve, the initial starting amount of the target template in experimental samples can be determined. Additional information about the performance of the qPCR reaction and various reaction parameters (including efficiency and $\mathrm{R}^{2}$ ) can be determined from this plot. 
Fig 4

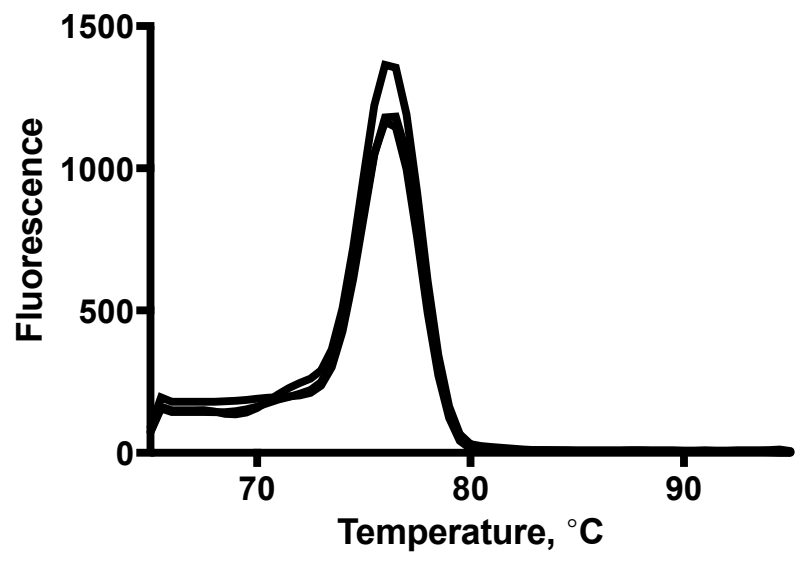

Fig 4. Melting curve. One peak in melting curve means there is no primer dimerization. 
Table 1

\begin{tabular}{|l|l|l|l|l|l|l|l|l|l|l|l|l|}
\hline & $\mathbf{1}$ & $\mathbf{2}$ & $\mathbf{3}$ & $\mathbf{4}$ & $\mathbf{5}$ & $\mathbf{6}$ & $\mathbf{7}$ & $\mathbf{8}$ & $\mathbf{9}$ & $\mathbf{1 0}$ & $\mathbf{1 1}$ & $\mathbf{1 2}$ \\
\hline A & $\begin{array}{l}\text { DNA } \\
\text { dil. } 1\end{array}$ & II & III & UI & II & III & & & & & & \\
\hline B & $\begin{array}{l}\text { DNA } \\
\text { dil. 2 }\end{array}$ & II & III & WT & II & III & & & & & & \\
\hline C & $\begin{array}{l}\text { DNA } \\
\text { dil. } 3\end{array}$ & II & III & AraC & II & III & & & & & & \\
\hline D & $\begin{array}{l}\text { DNA } \\
\text { dil. 4 }\end{array}$ & II & III & NT & II & III & & & & & & \\
\hline E & $\begin{array}{l}\text { DNA } \\
\text { dil. 5 }\end{array}$ & II & III & & & & & & & & & \\
\hline F & $\begin{array}{l}\text { DNA } \\
\text { dil. 6 }\end{array}$ & II & III & & & & & & & & & \\
\hline G & $\begin{array}{l}\text { DNA } \\
\text { dil. 7 }\end{array}$ & II & III & & & & & & & & & \\
\hline H & $\begin{array}{l}\text { DNA } \\
\text { dil. 8 }\end{array}$ & II & III & & & & & & & & & \\
\hline
\end{tabular}

Table 1. Layout plan for qPCR plate. Vaccinia gDNA dilution series (DNA dil. 1-8), Uninfected (UI), vaccinia wind type infected (WT), vaccinia WT infected and AraC treated (AraC), negative control (NT, 'no template'), technical triplicates (roman numerals). 
Table 2

A

\begin{tabular}{|l|l|}
\hline \multicolumn{2}{|l|}{ Negative controls } \\
\hline No template & Detection of primer dimers and contamination \\
\hline No reverse transcription & Detection of genomic DNA contamination \\
\hline Positive controls & \\
\hline Same sample, different target & Quality of reagents and normalization \\
\hline Same target, different sample & Quality of reagents \\
\hline
\end{tabular}

B

\begin{tabular}{|l|l|}
\hline \multicolumn{2}{|l|}{ Normalization to the original cell number/sample quantity } \\
\hline+ can minimize variability & $\begin{array}{l}\text { - only approximation } \\
\text { - does not account biases in DNA/RNA } \\
\text { extraction } \\
\text { - only for cell culture/blood samples }\end{array}$ \\
\hline Normalization to the total DNA/RNA mass & $\begin{array}{l}\text { - DNA/RNA mass determined by } \\
\text { photospectrometer is not accurate } \\
\text { - does not control for differences in efficiency } \\
\text { in reverse transcription or qPCR reactions } \\
\text { - very sensitive to operator variation }\end{array}$ \\
\hline Normalization to one or more housekeeping genes \\
\hline $\begin{array}{l}\text { + controls for DNA/RNA quality and quantity, } \\
\text { and differences in both reverse transcriptase } \\
\text { and qPCR efficiencies }\end{array}$ & $\begin{array}{l}\text { - the gene(s) must be present at consistent } \\
\text { level in all samples }\end{array}$ \\
\hline
\end{tabular}

Table 2. A) Commonly used negative and positive controls and their aims. B) Commonly used qPCR normalization methods and their advantages and disadvantages. 
Table 3

\begin{tabular}{|l|l|l|}
\hline Sample & Average Ct & $\begin{array}{l}\text { Calculated } \\
\text { DNA mass (pg) }\end{array}$ \\
\hline UI & N.D. & - \\
\hline WT & 19.00 & 73.83 \\
\hline AraC & 28.17 & 0.16 \\
\hline NT & N.D. & - \\
\hline
\end{tabular}

Table 3. Calculating the absolute amounts of starting material. The amount of starting material was calculated by placing the average sample Ct values into equation gained from standard curve. In this example experiment the equation was $\mathrm{x}=\mathrm{e}^{\wedge}((25.415-\mathrm{y}) / 1.492)$, where $\mathrm{x}$ is the calculated DNA mass and $\mathrm{y}$ is the average Ct of the sample. Uninfected sample (UI), vaccinia wild type infection (WT), vaccinia DNA replication inhibitor treated infected samples (AraC), negative control (NT, 'no template'), nondetermined (N.D.) 
Table 4.

\begin{tabular}{|c|c|c|c|c|c|c|c|c|c|c|c|c|}
\hline & 1 & 2 & 3 & 4 & 5 & 6 & 7 & 8 & 9 & 10 & 11 & 12 \\
\hline A & $\begin{array}{l}\text { Ctrl } \\
\text { UI } \\
2 \mathrm{~h} \\
\end{array}$ & II & III & $\begin{array}{l}\text { Ctrl } \\
\mathrm{UI} \\
4 \mathrm{~h} \\
\end{array}$ & II & III & $\begin{array}{l}\text { Ctrl } \\
\text { UI } \\
8 \mathrm{~h} \\
\end{array}$ & II & III & & & \\
\hline B & $\begin{array}{l}\text { Ctrl } \\
\text { WT } \\
2 \mathrm{~h} \\
\end{array}$ & II & III & $\begin{array}{l}\text { Ctrl } \\
\text { WT } \\
4 \mathrm{~h} \\
\end{array}$ & II & III & $\begin{array}{l}\text { Ctrl } \\
\text { WT } \\
8 \mathrm{~h}\end{array}$ & II & III & & & \\
\hline C & $\begin{array}{l}\text { Ctrl } \\
\mathrm{H} \\
2 \mathrm{~h} \\
\end{array}$ & II & III & $\begin{array}{l}\text { Ctrl } \\
\mathrm{H} \\
4 \mathrm{~h}\end{array}$ & II & III & $\begin{array}{l}\text { Ctrl } \\
\mathrm{H} \\
8 \mathrm{~h}\end{array}$ & II & III & & & \\
\hline D & $\begin{array}{l}\text { Ctrl } \\
\text { NT }\end{array}$ & II & III & $\begin{array}{l}\text { Ctrl } \\
\text { NT }\end{array}$ & II & III & $\begin{array}{l}\text { Ctrl } \\
\text { NT }\end{array}$ & II & III & & & \\
\hline $\mathbf{E}$ & $\begin{array}{l}\mathrm{J} 2 \\
\mathrm{UI} \\
2 \mathrm{~h}\end{array}$ & II & III & $\begin{array}{l}\text { G8 } \\
\text { UI } \\
4 \mathrm{~h}\end{array}$ & II & III & $\begin{array}{l}\mathrm{J} 2 \\
\mathrm{UI} \\
8 \mathrm{~h}\end{array}$ & II & III & & & \\
\hline $\mathbf{F}$ & $\begin{array}{l}\mathrm{J} 2 \\
\mathrm{WT} \\
2 \mathrm{~h}\end{array}$ & II & III & $\begin{array}{l}\text { G8 } \\
\text { WT } \\
4 \mathrm{~h}\end{array}$ & II & III & $\begin{array}{l}\mathrm{J} 2 \\
\mathrm{WT} \\
8 \mathrm{~h}\end{array}$ & II & III & & & \\
\hline G & $\begin{array}{l}\mathrm{J} 2 \\
\mathrm{H} \\
2 \mathrm{~h} \\
\end{array}$ & II & III & $\begin{array}{l}\text { G8 } \\
\mathrm{H} \\
4 \mathrm{~h} \\
\end{array}$ & II & III & $\begin{array}{l}\mathrm{J} 2 \\
\mathrm{H} \\
8 \mathrm{~h} \\
\end{array}$ & II & III & & & \\
\hline H & $\begin{array}{l}\mathrm{J} 2 \\
\mathrm{NT}\end{array}$ & II & III & $\begin{array}{l}\text { G8 } \\
\text { NT } \\
4 \mathrm{~h}\end{array}$ & II & III & $\begin{array}{l}\mathrm{J} 2 \\
\mathrm{NT}\end{array}$ & II & III & & & \\
\hline
\end{tabular}

Table 4. Layout plan for qRT-PCR. Uninfected (UI), vaccinia wind type infected (WT), vaccinia WT infected and Hoechst treated (H), negative control (NT, 'no template'), housekeeping gene (GAPDH), vaccinia early gene (J2), vaccinia intermediate gene (G8), vaccinia late gene (F17), technical triplicates (roman numerals). 
Table 5

A
\begin{tabular}{|l|l|l|l|}
\hline Ct & $\begin{array}{l}\text { 2h, } \\
\text { GAPDH }\end{array}$ & $\begin{array}{l}\text { 4h, } \\
\text { GAPDH }\end{array}$ & $\begin{array}{l}\text { 8h, } \\
\text { GAPDH }\end{array}$ \\
\hline UI & 18.04 & 17.36 & 17.39 \\
\hline WT & 18.59 & 18.86 & 21.57 \\
\hline H & 18.38 & 18.40 & 19.65 \\
\hline NT & N.D. & N.D. & N.D. \\
\hline & 2h, & 4h, & 8h, \\
& J2 & G8 & F17 \\
\hline UI & 31.86 & 30.00 & 29.50 \\
\hline WT & 12.93 & 21.33 & 15.28 \\
\hline H & 12.49 & 28.30 & 16.22 \\
\hline NT & N.D. & N.D. & N.D. \\
\hline
\end{tabular}

B
\begin{tabular}{|l|l|l|l|}
\hline$\Delta$ Ct & 2h, J2 & 4h, G8 & 8 h, F17 \\
\hline UI & 13.82 & 12.64 & 12.11 \\
\hline WT & -5.65 & 2.47 & -6.29 \\
\hline H & -5.88 & 9.90 & -3.42 \\
\hline
\end{tabular}

C
\begin{tabular}{|l|l|l|l|}
\hline$\Delta \Delta \mathbf{C t}$ & $\mathbf{2 h}, \mathbf{J 2}$ & $\mathbf{4 h}, \mathbf{G 8}$ & $\mathbf{8 h}, \mathbf{F 1 7}$ \\
\hline UI & 19.47 & $\mathbf{1 0 . 1 6}$ & $\mathbf{1 8 . 3 9}$ \\
\hline WT & $\mathbf{0}$ & $\mathbf{0}$ & $\mathbf{0}$ \\
\hline H & -0.23 & $\mathbf{7 . 4 2}$ & 2.87 \\
\hline
\end{tabular}

$\mathrm{D}$

\begin{tabular}{|l|l|l|l|}
\hline Final & $2 \mathrm{~h}, \mathrm{J2}$ & $4 \mathrm{~h}, \mathrm{G8}$ & $8 \mathrm{~h}, \mathrm{F17}$ \\
\hline UI & $1.38 \times 10^{-6}$ & $8.72 \times 10^{-4}$ & $2.91 \times 10^{-6}$ \\
\hline WT & 1 & 1 & 1 \\
\hline H & 1.17 & $5.82 \times 10^{-3}$ & 0.14 \\
\hline
\end{tabular}

Table 5. A) Average Ct results from qRT-PCR run. B) Calculated $\Delta \mathrm{Ct}$ values $\left(\mathrm{Ct}_{\mathrm{Gene}}\right.$ of interest $-\mathrm{Ct}_{\text {Housekeeping }}$ gene) for qRT-PCR results. Values were calculated by subtracting the Ct value of the housekeeping gene from Ct value of the same 'gene of interest' sample. C) Calculated $\Delta \Delta \mathrm{Ct}$ values $\left(\Delta \mathrm{Ct}_{\mathrm{Gene}}\right.$ of interest $^{-}$ $\Delta \mathrm{Ct}_{\text {Control }}$ ) for qRT-PCR results. Values were calculated by subtracting the $\Delta \mathrm{Ct}$ value of the chosen control sample (WT) from $\Delta$ Ct of gene of interest. D) Final relative quantification. Values were calculated by equation $0.5^{\wedge}(\Delta \Delta \mathrm{Ct})$. Uninfected (UI), vaccinia wind type infected (WT), vaccinia WT infected and Hoechst treated $(\mathrm{H})$, negative control (NT, 'no template'), housekeeping gene (GAPDH), vaccinia early gene (J2), vaccinia intermediate gene (G8), vaccinia late gene (F17) 